\title{
Thiacalix[4]arenes with Triple Bonds at the Lower Rim: Synthesis and Structure
}

\author{
Nataly A. Epifanova ${ }^{a}{ }^{a}$ Elena V. Popova, ${ }^{a}$ Svetlana E. Solovieva, ${ }^{a}$ Shamil K. Latypov $^{a}$ \\ Igor S. Antipin, ${ }^{a, b}$ and Alexander I. Konovalov ${ }^{a, b}$
}

Dedicated to Academician Irina P. Beletskaya on the occasion of her birthday

\author{
${ }^{a}$ A.E. Arbuzov Institute of Organic and Physical Chemistry KazSC RAS, 420088 Kazan, Russia \\ ${ }^{\mathrm{b}}$ Kazan (Volga region) Federal University, 420008 Kazan, Russia \\ @Corresponding author E-mail: svsol@iopc.ru
}

\begin{abstract}
Reaction of thiacalixarenes with propargyl bromide in the presence of potassium or cesium carbonates leads mainly to mixture of the corresponding tetrasubstituted derivatives adopting 1,3-alternate and partial cone conformations. Sodium salts like carbonate and hydride are not effective as the base for the etherification of lower rim of thiacalix[4]arenes by propargyl bromide. It was established that propargyl derivatives of thiacalix[4]arenes are in conformational exchange between forms due rotation of one aryl ring.
\end{abstract}

Keywords: Thiacalexarenes, triple bonds, propargyl bromide, conformational exchange.

\section{Тиакаликсарены с тройными связями на нижнем ободе: синтез и структура}

\author{
Н. А. Епифанова, ${ }^{a}$ Е. В. Попова, ${ }^{a}$ C. Е. Соловьева, ${ }_{1} @$ Ш. К. Аатыпов, ${ }^{a}$ \\ И. С. Антипин, ${ }^{\mathrm{a}, \mathrm{b}}$ А. И. Коновалов ${ }^{\mathrm{a}, \mathrm{b}}$
}

Посвящается акаgемику И. П. Белецкой по случаю её юбилея

\begin{abstract}
${ }^{\mathrm{a}}$ Институт органической и физической химии им. А.Е. Арбузова Казанского научного цчентра Российской академии наук, 420088 Казань, Россия

'Казанский (Приволжский) федеральный университет, 420008 Казань, Россия

@E-mail: svsol@iopc.ru
\end{abstract}

\begin{abstract}
Реакции тиакаликсаренов с пропаргилбромидом в присутствии карбонатов калия или цеезия приводят к смеси соответствующих тетразамещенных производных в конформациях частичный конус и 1,3-альтернат, находящихся в равновесии. Соли натрия- карбонат или гидрид неэффективнь в качестве основания для этерификации нижнего обода тиакаликсаренов пропаргилбромидом.
\end{abstract}

Ключевые слова: Тиакаликсарены, тройные связи, пропаргил бромид, конформационный обмен. 


\section{Introduction}

Atom economy is an important concept of green chemistry philosophy. Last decade new synthetic approaches, in particular, atom-economical reactions with a maximal using of "molecular material," as well as highly selective and thermodynamically-favored reactions are actively used in organic and supramolecular chemistry. Term of "click chemistry" introduced by K.B. Sharpless in $2001^{[1]}$ is to describe efficient and selective reactions that can be used to join molecules together rapidly and in high yield. One of the most promising reaction corresponding to "click reaction" criteria is the copper-catalyzed 1,3-dipolar cycloaddition of an triple bond with an azide to yield triazole fragment.

The functionalization of (thia)calix[4] arene derivatives with closely located functional groups is often difficult due to the sharp decrease of their reactivity and even change of the chemical reaction direction. ${ }^{[2,3]}$ From this point of view the modular approach of click chemistry seems to be a perspective to design more sophisticated receptor and nanosized structures. Moreover, there is no need to protect the large number of functional groups during transformation. So, (thia)calix[4]arene 1-4 derivatives containing triple bonds on upper and/or lower rims of macrocycles are interesting as starting materials for further transformations.

However, the introduction of triple bonds at the upper rim of calix[4]arenes requires prior a functionalization of aromatic rings para-positions. The starting reagents for the introduction of triple bonds on the upper rim using a transition metal catalyzed cross-coupling reaction ${ }^{[4]}$ are corresponding iodine and less reactive bromine calixarene derivatives. ${ }^{[5,6]}$ In the case of thiacalix[4]arenes the synthesis of $p$-bromoderivatives was only described. ${ }^{[7]}$ For this reason only one example of the synthesis of thiacalix[4]arenes derivatives containing triple bonds at the upper rim is known. ${ }^{[8]}$

On the contrary, the functionalization of the lower rim can be easily achieved by direct alkylation of the phenolic groups using reagents containing triple bonds. A number of derivatives of classical calix[4]arenes with propargyl fragments are known. ${ }^{[9-11]}$ However, an etherification of free phenolic groups of thiacalix[4]arenes by propargyl halogenides is not investigated.

\section{Experimental}

The solvents and reagents were purified before use according to known procedures. ${ }^{[12]}$ The Acros chemicals were used.

The NMR experiments were carried out on a Bruker Avance $600 \mathrm{NMR}$ spectrometer in $\mathrm{CDCl}_{3}$ at $30{ }^{\circ} \mathrm{C}$. Chemical shifts were referred to residual signal of $\mathrm{CDCl}_{3}\left(\delta_{\mathrm{H}} 7.26\right)$.

The IR spectra were recorded on Bruker Vector 22 spectrometer in $\mathrm{KBr}$ pellets at $4 \mathrm{~cm}^{-1}$ resolution using 64 scans in the wavenumber range of $400-4000 \mathrm{~cm}^{-1}$.

The molecular mass spectra were measured on a MALDI-TOF Ultraflex III mass spectrometer as solutions in the appropriate solvents in the concentration range of $10^{-3}-10^{-5} \mathrm{~mol} \cdot \mathrm{l}^{-1}$. (E)-2-Cyano-3(4-hydroxyphenyl)acrylic acid, 1,8,9-trihydroxyanthracene, or $p$-nitroaniline were used as the matrix. The purity of the compounds was monitored by TLC on Silufol UV 254 and Fluka 0.060-0.2 mm plate. The melting points were determined on a Boetius PHMK 05 micro melting point apparatus. All reactions were carried out under argon.

Calix[4]arenes $\mathbf{3}$ and $\mathbf{4}$ were synthesized according to the known procedures,${ }^{[13,14]}$ accordingly.
25,26,27,28-Tetrakis (propinyloxy)-2,8,14,20-tetrathiacalix[4] arene, $3 \boldsymbol{b}$ - $\boldsymbol{d}$. A mixture of thiacalix[4]arene 3 ( $1 \mathrm{~g}, 2 \mathrm{mmol})$, propargyl bromide $(3.808 \mathrm{~g}, 0.032 \mathrm{~mol})$, cesium/potassium carbonate $(0.04 \mathrm{~mol})$ was kept at boiling in acetone $(100 \mathrm{ml})$ with continuous stirring for 50 hours. The reaction progress was monitored by TLC using a 1:2 hexane-toluene mixture as the eluent. After completion of the reaction, the precipitate was filtered off and dissolved in diethyl ether $(6 \mathrm{ml})$. Then hexane $(15 \mathrm{ml})$ was added, the precipitate $(86 / 82 \%$, as a mixture of conformers 1,3-alternate, partial cone and cone) was formed and filtered. Individual 1,3-alternate conformer $\mathbf{3 b}$ was isolated (41/38 \%) after column chromatography (eluent: hexane:toluene $=1: 2$ ) and a mixture of stereoisomers partial cone and the cone, which could not be separated.

3b. MALDI TOF $(\mathrm{m} / \mathrm{z}): 648[\mathrm{M}]^{+}, 671[\mathrm{M}+\mathrm{Na}]^{+}, 687[\mathrm{M}+\mathrm{K}]^{+}$, $781[\mathrm{M}+\mathrm{Cs}]^{+}$. IR $(\mathrm{KBr}) v_{\max } \mathrm{cm}^{-1}: 3296(\mathrm{C} \equiv \mathrm{CH}), 2120(\mathrm{C} \equiv \mathrm{C}) .{ }^{1} \mathrm{H}$ NMR $\left(\mathrm{CDCl}_{3}, 303 \mathrm{~K}\right) \delta_{\mathrm{H}}$ ppm: $7.02\left(8 \mathrm{H}, \mathrm{d} \delta_{\mathrm{HH}}=5.71 \mathrm{~Hz}, \mathrm{H}_{\text {ary }}\right)$, $6.72\left(4 \mathrm{H}, \mathrm{t} \mathcal{J}_{\mathrm{HH}}=7.62 \mathrm{~Hz}, \mathrm{H}_{\text {ary }}\right), 5.04\left(8 \mathrm{H}, \mathrm{d} J_{\mathrm{HH}}^{4}=2.54 \mathrm{~Hz}, \mathrm{OCH}_{2}\right)$, $2.47\left(4 \mathrm{H}, \mathrm{t} J_{\mathrm{HH}}^{4}=2.22 \mathrm{~Hz}, \mathrm{CH}\right)$. M.p. $159-161^{\circ} \mathrm{C} . R_{\mathrm{f}}$ (toluene:hexane $=2: 1) 0.30$.

3c, 3d. MALDI TOF $(\mathrm{m} / \mathrm{z}): 648[\mathrm{M}]^{+}, 671[\mathrm{M}+\mathrm{Na}]^{+}, 687$ $[\mathrm{M}+\mathrm{K}]^{+}, 781[\mathrm{M}+\mathrm{Cs}]^{+}$. IR $(\mathrm{KBr}) v_{\max } \mathrm{cm}^{-1}: 3296(\mathrm{C} \equiv \mathrm{CH}), 2120$ $(\mathrm{C} \equiv \mathrm{C}) . R_{\mathrm{f}}$ (toluene:hexane $\left.=2: 1\right) 0.80$.

3c. ${ }^{1} \mathrm{H}$ NMR $\left(\mathrm{CDCl}_{3}, 303 \mathrm{~K}\right) \delta_{\mathrm{H}}$ ppm: $7.82\left(2 \mathrm{H}, \mathrm{d} \mathcal{J}_{\mathrm{HH}}=7.6\right.$ $\left.\mathrm{Hz}, \mathrm{H}_{10}\right), 7.66\left(2 \mathrm{H}, \mathrm{dd} \mathcal{J}_{\mathrm{HH}}^{3}=7.6 \mathrm{~Hz}, J_{\mathrm{HH}}^{4}=1.6 \mathrm{~Hz}, \mathrm{H}_{3}\right), 7.4(2 \mathrm{H}$, $\left.\mathrm{d} \mathcal{S}_{\mathrm{HH}}=7.6 \mathrm{~Hz}, \mathrm{H}_{6}\right), 7.07\left(1 \mathrm{H}, \mathrm{t} \mathcal{\beta}_{\mathrm{HH}}=7.92 \mathrm{~Hz}, \mathrm{H}_{11}\right), 6.94(1 \mathrm{H}, \mathrm{t}$ $\left.\mathcal{J}_{\mathrm{HH}}=7.92 \mathrm{~Hz}, \mathrm{H}_{7}\right), 6.89\left(2 \mathrm{H}, \mathrm{dd}{\mathcal{J}_{\mathrm{HH}}^{3}}^{3}=7.48 \mathrm{~Hz}, J_{\mathrm{HH}}^{4}=1.28 \mathrm{~Hz}, \mathrm{H}_{1}\right)$, $6.66\left(2 \mathrm{H}, \mathrm{t} \mathcal{J}_{\mathrm{HH}}=7.92 \mathrm{~Hz}, \mathrm{H}_{2}\right), 4.90\left(2 \mathrm{H}, \mathrm{d}^{4}{ }_{\mathrm{HH}}=2.24 \mathrm{~Hz}, \mathrm{H}_{12}\right), 4.85$ $\left(4 \mathrm{H}, \mathrm{d} J_{\mathrm{HH}}^{4}=2.52 \mathrm{~Hz}, \mathrm{H}_{4}\right), 4.27\left(2 \mathrm{H}, \mathrm{d} J_{\mathrm{HH}}^{4}=2.24 \mathrm{~Hz}, \mathrm{H}_{8}\right), 2.60(1 \mathrm{H}$, $\left.\mathrm{t} J_{\mathrm{HH}}^{4}=2.24 \mathrm{~Hz}, \mathrm{H}_{13}\right), 2.51\left(2 \mathrm{H}, \mathrm{t} J_{\mathrm{HH}}^{4}=2.52 \mathrm{~Hz}, \mathrm{H}_{5}\right), 2.18(1 \mathrm{H}, \mathrm{t}$ $J_{\mathrm{HH}}^{4}=2.24 \mathrm{~Hz}, \mathrm{H}_{9}$ ) (atom numbering is given in Figure 1).

3d. ${ }^{1} \mathrm{H}$ NMR $\left(\mathrm{CDCl}_{3}, 303 \mathrm{~K}\right) \delta_{\mathrm{H}} \mathrm{ppm}: 7.60\left(8 \mathrm{H}, \mathrm{d} \mathcal{\beta}_{\mathrm{HH}}=7.92\right.$ $\left.\mathrm{Hz}, \mathrm{H}_{\text {ary }}\right), 6.87\left(4 \mathrm{H}, \mathrm{t} \mathcal{\beta}_{\mathrm{HH}}=7.62 \mathrm{~Hz}, \mathrm{H}_{\text {ary }}\right), 4.74\left(8 \mathrm{H}, \mathrm{d} J_{\mathrm{HH}}^{4}=2.52 \mathrm{~Hz}\right.$, $\left.\mathrm{OCH}_{2}\right), 4.48\left(4 \mathrm{H}, \mathrm{t} J_{\mathrm{HH}}^{4}=2.2 \mathrm{~Hz}, \mathrm{CH}\right)$.

5,11,17,23-Tetra-tert-butyl-25,26,27,28-tetrakis(propinyloxy)-2,8,14,20-tetrathiacalix[4]arene, $4 \boldsymbol{b}$-c. A mixture of p-tert-butyl-thiacalix[4]arene 4 (1 g, $1.4 \mathrm{mmol})$, propargyl bromide $(2.67 \mathrm{~g}, 0.0224 \mathrm{~mol})$, cesium/potassium carbonate $(0.028 \mathrm{~mol})$ was kept at boiling in acetone $(80 \mathrm{ml})$ with continuous stirring for 50 hours. The reaction progress was monitored by TLC using 1:2 hexane-chloroform mixture as an eluent. After completion of the reaction, the precipitate was filtered off and dissolved in chloroform $(8 \mathrm{ml})$. Then methanol $(20 \mathrm{ml})$ was added, the precipitate $(76 / 77$ $\%$ ) as a mixture of conformers 1,3-alternate and partial cone) was formed and filtered.

4b, 4c. MALDI TOF $(\mathrm{m} / \mathrm{z}): 872[\mathrm{M}]^{+}, 895[\mathrm{M}+\mathrm{Na}]^{+}, 911$ $[\mathrm{M}+\mathrm{K}]^{+}$. IR $(\mathrm{KBr}) v_{\max } \mathrm{cm}^{-1}: 3290(\mathrm{C} \equiv \mathrm{CH}), 2122(\mathrm{C} \equiv \mathrm{C}) \cdot R_{\mathrm{f}}$ (acetone: hexane $=1: 20) 0.60$ and 0.24 , correspondingly.

4b. ${ }^{1} \mathrm{H}$ NMR $\left(\mathrm{CDCl}_{3}, 303 \mathrm{~K}\right) \delta_{\mathrm{H}}$ ppm: $7.58\left(8 \mathrm{H}, \mathrm{s} \mathrm{H}_{\text {aryl }}\right), 4.68$ $\left(8 \mathrm{H}, \mathrm{d} J_{\mathrm{HH}}^{4}=2.39 \mathrm{~Hz}, \mathrm{OCH}_{2}\right), 2.42\left(4 \mathrm{H}, \mathrm{t}, J_{\mathrm{HH}}^{4}=2.39 \mathrm{~Hz}, \mathrm{CH}\right)$, $1.27\left(36 \mathrm{H}, \mathrm{s}{ }^{t} \mathrm{Bu}\right)$.

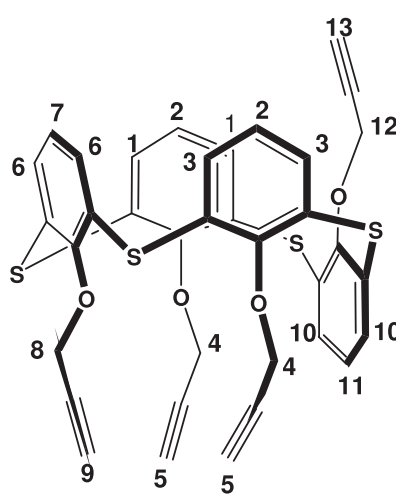

$3 \mathbf{c}$

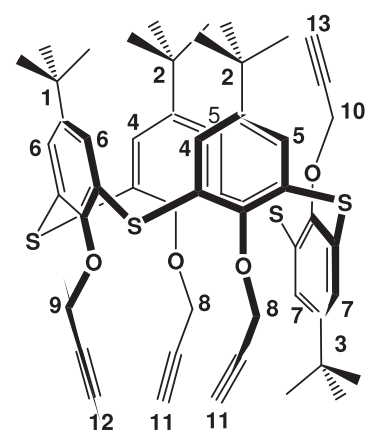

$4 c$
Figure 1. Atom numbering in compounds $\mathbf{3 c}$ and $\mathbf{4 c}$. 
4c. ${ }^{1} \mathrm{H}$ NMR $\left(\mathrm{CDCl}_{3}, 303 \mathrm{~K}\right) \delta_{\mathrm{H}} \mathrm{ppm}: 7.90\left(2 \mathrm{H}, \mathrm{s} \mathrm{H}_{7}\right), 7.57$ $\left(2 \mathrm{H}, \mathrm{d} J_{\mathrm{HH}}^{4}=2.4 \mathrm{~Hz}, \mathrm{H}_{5 .)} 7.52\left(2 \mathrm{H}, \mathrm{s} \mathrm{H}_{6}\right), 7.05\left(2 \mathrm{H}, \mathrm{d} J_{\mathrm{HH}}^{4}=2.36 \mathrm{~Hz}\right.\right.$, $\left.\mathrm{H}_{4}\right) 4.80\left(2 \mathrm{H}, \mathrm{d} J_{\mathrm{HH}}^{4}=2.76 \mathrm{~Hz}, \mathrm{H}_{10}\right), 4.79\left(4 \mathrm{H}, \mathrm{d} J_{\mathrm{HH}}^{4}=2.72 \mathrm{~Hz}, \mathrm{H}_{8}\right)$, $4.50\left(2 \mathrm{H}, \mathrm{d}^{4}{ }_{\mathrm{HH}}=2.76 \mathrm{~Hz} \mathrm{H}_{9}\right), 2.52\left(2 \mathrm{H}, \mathrm{t} J_{\mathrm{HH}}^{4}=2.39 \mathrm{~Hz}, \mathrm{H}_{11}\right), 2.45$ $\left(1 \mathrm{H}, \mathrm{t} J_{\mathrm{HH}}^{4}=2.39 \mathrm{~Hz}, \mathrm{H}_{13}\right), 2.18\left(1 \mathrm{H}, \mathrm{t} J_{\mathrm{HH}}^{4}=2.4 \mathrm{~Hz}, \mathrm{H}_{12}\right), 1.43(9 \mathrm{H}$, $\left.\mathrm{s}^{t} \mathrm{Bu}_{3}\right), 1.31\left(9 \mathrm{H}, \mathrm{s}{ }^{t} \mathrm{Bu}_{1}\right), 1.07\left(\mathrm{~s} 18 \mathrm{H},{ }^{t} \mathrm{Bu}_{2}\right)$ (atom numbering is given in Figure 1).

\section{Results and Discussion}

The etherification of the lower rim (the phenol groups) is a standard procedure to modify the (thia)calix[4]arene platform..$^{[2,15]}$ Accordingly, several groups have investigated ${ }^{[15,16-18]}$ the functionalization of (thia)calixarenes 1-4 by alkyl halides using the acetone(acetonitrile) $/ \mathrm{M}_{2} \mathrm{CO}_{3}$ reaction system $(\mathrm{M} \equiv \mathrm{Na}, \mathrm{K}$, and $\mathrm{Cs})$. As a part of our research into the derivatization of lower rim of these macrocycles, ${ }^{[3,19-}$ ${ }^{31]}$ a systematic study of the reaction of thiacalix[4]arene 3 and $p$-tert-butylthiacalix[4]arene 4 with propargyl bromide in the presence of alkali metal carbonates (Scheme 1) was carried out. Obtained data are summarized in the Table 1.

The etherification reaction of $p$-tert-butylthiacalix[4]arene $\mathbf{4}$ and its de-tert-butylated analogue $\mathbf{3}$ in the presence of sodium carbonate in refluxing acetone leads to the formation of the complicated mixture of products with different degrees of substitution. After 50 hours of refluxing, almost $90 \%$ of the starting material remained unchanged. This result, not entirely unexpected, may be explained by the observation that the same reactions with alkyl iodide/bromide gave less than $2 \%$ yields of alkylation products. ${ }^{[16]}$ At the same time the more reactive allyl bromide (compared to alkyl bromides) in acetonitrile offered the compound $\mathbf{5}$ in 1,3-alternate conformation with $44 \%$ yield. ${ }^{[32]}$ Theoretically, propargyl bromide should be even more reactive than allyl bromide. So, the low yields of etherification reaction by propargyl bromide can be rationalized in term of its instability in the base media and low nucleophilic ability of sodium phenolates.

Application of the stronger base $\mathrm{NaH}$ in $\mathrm{DMF}$ at room temperature ${ }^{[15,18]}$ in the reactions with alkyl iodides usually leads to formation of the desired tetraalkylated products. For

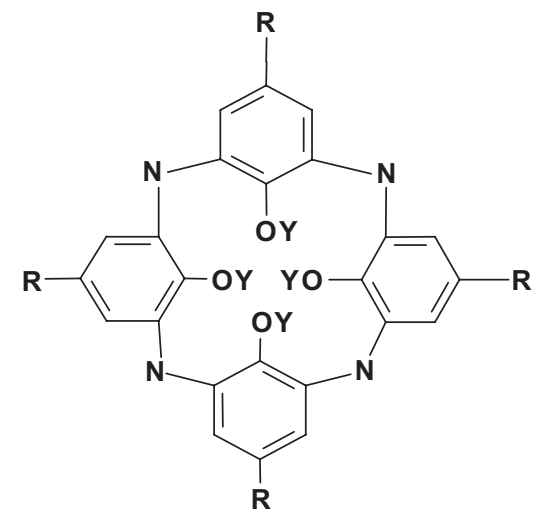

$$
\begin{array}{ll}
\text { 5: } \mathrm{X}=\mathrm{S} ; \mathrm{R}=\mathrm{H}, \mathrm{Y}=\mathrm{All} & \text { 8: } \mathrm{X}=\mathrm{CH}_{2} ; \mathrm{R}={ }^{t} \mathrm{Bu}, \mathrm{Y}={ }^{n} \mathrm{Pr} \\
\text { 6: } \mathrm{X}=\mathrm{S} ; \mathrm{R}={ }^{t} \mathrm{Bu}, \mathrm{Y}={ }^{n} \mathrm{Pr} & \text { 9: } \mathrm{X}=\mathrm{CH}_{2} ; \mathrm{R}=\mathrm{H}, \mathrm{Y}={ }^{n} \mathrm{Pr} \\
\text { 7: } \mathrm{X}=\mathrm{S} ; \mathrm{R}=\mathrm{H}, \mathrm{Y}={ }^{n} \mathrm{Pr} &
\end{array}
$$

examples, classic calix[4]arenes $\mathbf{1}$ and $\mathbf{2}$ at these conditions easily form tetrapropyl derivatives $\mathbf{8 , 9}$ in cone conformation in high yields ( 88 and $82 \%$, correspondingly) ${ }^{[15]}$ Thia-calix[4] arenes $\mathbf{3}$ and $\mathbf{4}$ are less reactive in these reactions. Alkylation of macrocycles $\mathbf{3}$ and $\mathbf{4}$ by propyl iodide gave tetra-derivatives in low overall yields (30\%) as mixture of different stereoisomers:
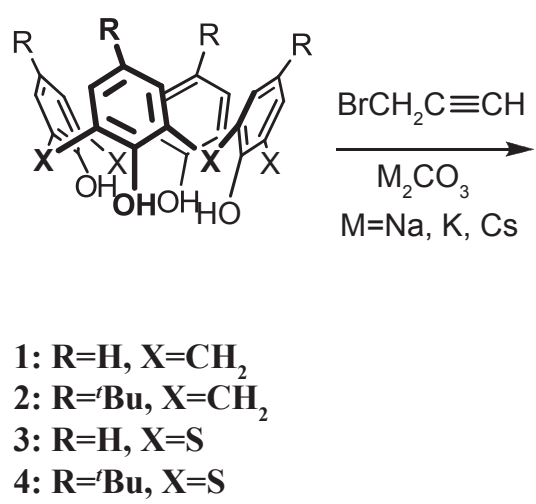

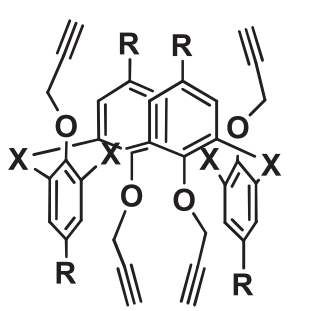

\begin{tabular}{l}
\hline $\mathrm{lb}$ \\
\hline $2 b$ \\
$3 b$ \\
$4 b$
\end{tabular}

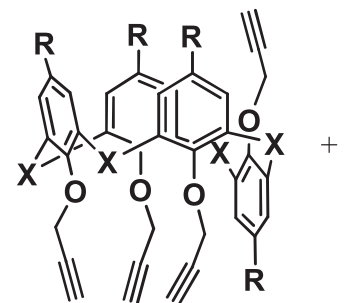

$1 \mathrm{c}$

$2 \mathrm{c}$

$3 c$

$4 \mathrm{c}$

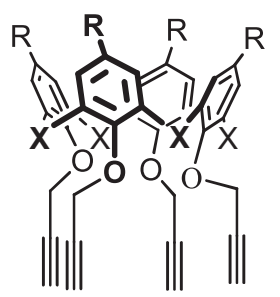

1d

2d

$3 d$

\begin{tabular}{|c|c|c|}
\hline Cation of alkali metal carbonate & Thiacalix[4] arene $\mathbf{3}$ & $p$-tert-Butyl-thiacalix[4]arene 4 \\
\hline $\mathrm{Na}^{+}$ & $\begin{array}{c}\text { The mixture of products with different } \\
\text { degrees of substitution }\end{array}$ & $\begin{array}{l}\text { The mixture of products with different degrees of } \\
\text { substitution }\end{array}$ \\
\hline $\mathrm{K}^{+}$ & $\begin{array}{c}\text { 3c-partial cone- } 49 \% \\
\text { 3b-1,3-alternate }-41 \% \\
\text { 3d- cone }-10 \%\end{array}$ & 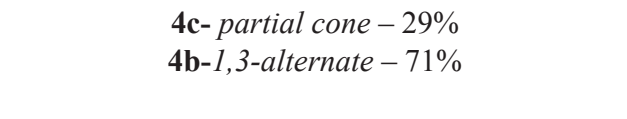 \\
\hline $\mathrm{Cs}^{+}$ & $\begin{array}{c}\text { 3c- partial cone }-54 \% \\
\text { 3b- } 1,3 \text {-alternate }-35.0 \% \\
\mathbf{3 d -} \text { - cone }-11 \%\end{array}$ & $\begin{array}{l}\text { 4c- partial cone }-33 \% \\
4 \mathbf{b}-1,3 \text {-alternate }-67 \%\end{array}$ \\
\hline
\end{tabular}

4d

Scheme 1.

Table 1. The stereoisomers yields of thiacalixarenes etherification by propargyl bromide according to NMR data of the reaction mixtures. 
cone, partial cone, 1,2- and 1,3-alternates. ${ }^{[18]}$ The interaction with propargyl bromide in the presence of $\mathrm{NaH}$ as a base did not offer the expected products of tetrasubstitution 3a-c, 4a-c. After two days, only the products with different degrees of substitution (less than $30 \%$ ) were found in the reaction mixture. Thus, we can conclude that sodium salts are not effective as the base for the etherification of lower rim of thiacalix[4] arenes by propargyl bromide.

Using potassium or cesium carbonates as the base for the thiacalix[4]arenes $O$-alkylation in the refluxing acetone or acetonitrile allows to synthesize desired tetraalkyl derivatives in the high yields. ${ }^{[16]}$ Despite the fact that the preparative synthesis leads to 1,3-alternate conformer, most thermodynamically stable isomer is partial cone that indicates on the kinetic control in the above reactions.

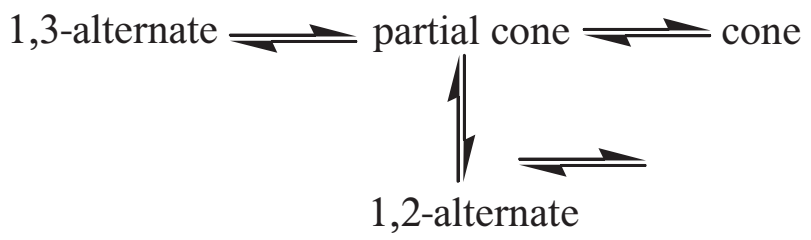

Scheme 1. Interconversion pathway for calix[4]arenes. ${ }^{[21]}$

Indeed, at the heating $(393 \mathrm{~K})$ of 1,3-alternate tetrapropyl derivative 7 in tetrachloroethane the equilibrium (Scheme 1) between all possible conformers: cone, partial cone, 1,2 - and 1,3-alternate, in a molar ratio of 31:58:4:7 was observed. ${ }^{[17]}$ The rate and the equilibrium constant of interconversion process were evaluated by NMR spectroscopy. The values of free energy conformers cone, 1,2 - and 1,3-alternate-7 relatively partial cone conformation were $0.48,1.99$ and $1.66 \mathrm{kcal} / \mathrm{mol}$, respectively. In the case of tetraallyl derivatives 1,3-alternate conformation is not stable in $\mathrm{CDCl}_{3}$ where it is slowly converted to the partial cone conformation already at room temperature. ${ }^{[32]}$ A complete transformation was achieved at $323 \mathrm{~K}$, where the partial cone stereoisomer seems to be dominant form.

Reaction of $\mathbf{3}$ with propargyl bromide in the presence of potassium or cesium carbonates leads to mixture of the corresponding 1,3-alternate $\mathbf{3 b}$ and partial cone $\mathbf{3 c}$ accompanied by small amounts of cone $\mathbf{3 d}$. Similarly, $\mathbf{4}$ yields 1,3-alternate $\mathbf{4 b}$ and partial cone $\mathbf{4 c}$. For p-tertbutylthiacalix[4]arene $\mathbf{4}$ the dominant stereoisomeric form is 1,3-alternate whereas for de-tert-butylated analogue 3 partial cone. This result can be rationalized in the terms of the steric repulsion between tert-butyl groups on the upper rim. So, three bulky tert-butyl groups located quiet closely to each other in partial cone destabilize significantly this conformer. Obviously, steric repulsion of tert-butyl groups should be smaller in the corresponding 1,3-alternate.

It was found that the nature of alkali metal ion of carbonates (K, Cs) doesn't influence on the products ratio (Table1). It seems likely that these reactions are thermodynamically controlled. This suggestion will be correct if there is conformational exchange at the reaction temperature. A number of facts indicates it. First, the mixture of stereoisomers $\mathbf{4 b}$ and $\mathbf{4} \mathbf{c}$ with different $R_{\mathrm{f}}$ factors ( 0.60 and 0.24 ) according to TLC was not separated by column chromatography. Possible reason of such result is rather fast transformation of conformers to each other during purification. Second, broadening of practically all ${ }^{1} \mathrm{H}$ resonances also indicates on additional conformational exchange with a free energy barrier slightly lower than for a single aryl ring inversion. ${ }^{[26,33]}$ Besides 1D DPFGNOE experiment also revealed chemical exchange between these conformations.

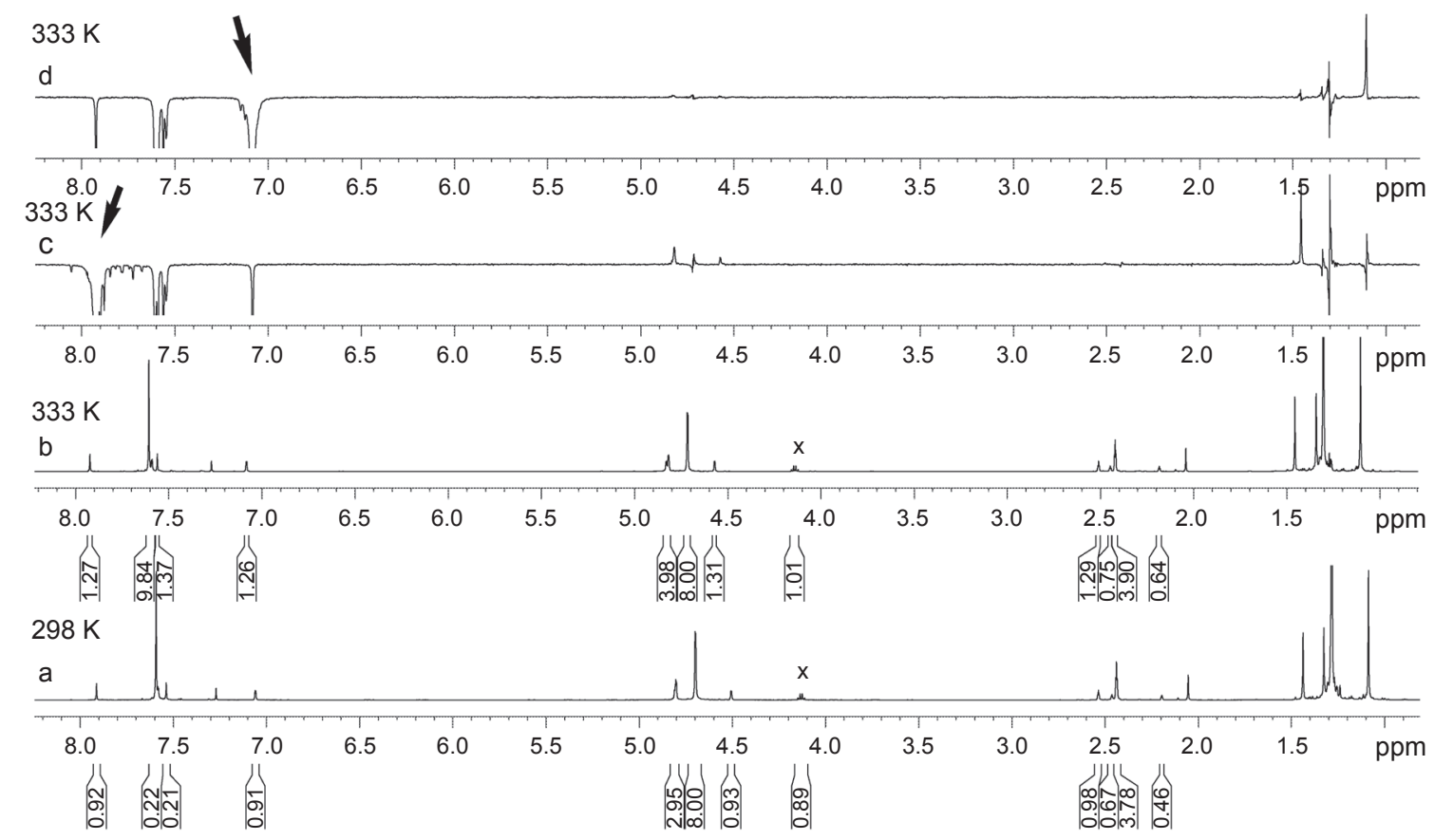

Figure 2. ${ }^{1} \mathrm{H}$ NMR of the mixture of $\mathbf{4 b}$ and $\mathbf{4} \mathbf{c}$ after column chromatography in $\mathrm{CDCl}_{3}$ at $298 \mathrm{~K}$ (a), $333 \mathrm{~K}$ (b) and $1 \mathrm{D}$ ROESY spectra at $333 \mathrm{~K}(\mathrm{c}, \mathrm{d})$. Excited protons are marked by array (x denotes impurity). 
${ }^{1} \mathrm{H}$ NMR spectra of the mixture of $\mathbf{4 b}$ and $\mathbf{4 c}$ after column chromatography in $\mathrm{CDCl}_{3}$ at room temperature presumably correspond to the mixture of at least two major conformations, 1,3-alternate and partial cone first one being approximately two times more populated (2.06:1 according to $-\mathrm{CH}_{2}$ - proton integrals, Figure $2 \mathrm{a}$ ). These forms are in exchange and temperature should affect their populations. Indeed, at $\mathrm{T}=333 \mathrm{~K}$, according to integral intensities $\left(\mathrm{CH}_{2}\right.$ proton integrals) in ${ }^{1} \mathrm{H}$ NMR spectra (Figure $2 \mathrm{~b}$ ), the gap in populations is diminished notable (1.51:1).

NOE experiments (in rotation frame) at $\mathrm{T}=333 \mathrm{~K}$ allows unequivocally prove that there is an exchange between these forms, viz. there are negative NOE's due to chemical exchange (saturation transfer) and positive NOE's due to dipole-dipole interactions (close proximity). For example, if to excite one of aromatic protons of partial cone conformer (Figure $2 \mathrm{c}$ and $2 \mathrm{~d}$ ) there are negative echoes on other protons of the partial cone and 1,3-alternate conformers as well.

The structure of all synthesized compounds was established by ${ }^{1} \mathrm{H}$ NMR, IR-spectroscopy and MALDI-TOF mass-spectrometry. While the assignment of the partial cone form is unambiguous, the choice between 1,3-alternate and cone conformers is not straightforward because due to high symmetry of both forms the multiplicity and intensity of proton signals are similar. To this end NOE measurements are particular useful to discriminate these structures.

For example, for compound $\mathbf{3 b}$ there are stereoselective NOE's between the protons of propargyl substituents and aromatic rings. Namely, excitation of the $m$ - and $p$-aromatic proton $\mathrm{H}-1,2$ gave rise to an NOE enhancement at the methine (H-3) and methylene (H-4) protons of the lower rim substituents (Figure 3b, c). Similarly the enhancements of the $m$ - and $p$-aromatic proton $\mathrm{H}-1,2$ were detected after the selective excitation of the $\mathrm{H}-3$ or $\mathrm{H}-4$ protons (Figure $3 \mathrm{~d}, \mathrm{e})$. These data unequivocally confirm 1,3-alternate stereisomeric form of the macrocycle $\mathbf{3 b}$.

\section{Conclusions}

The etherification of $p$-tert-butylthiacalix[4]arene and its de-tert-butylated analogue with propargyl bromide in the presence of alkali metal carbonates in refluxing acetone was investigated. Sodium salts like carbonate and hydride are not effective as the base in this reaction. In the presence of potassium or cesium carbonates mixtures of the corresponding tetrasubstituted derivatives adopting 1,3-alternate and partial cone conformations are formed. It was established that propargyl derivatives of thiacalix[4]arenes are in conformational exchange between forms due to rotation of one aryl ring.

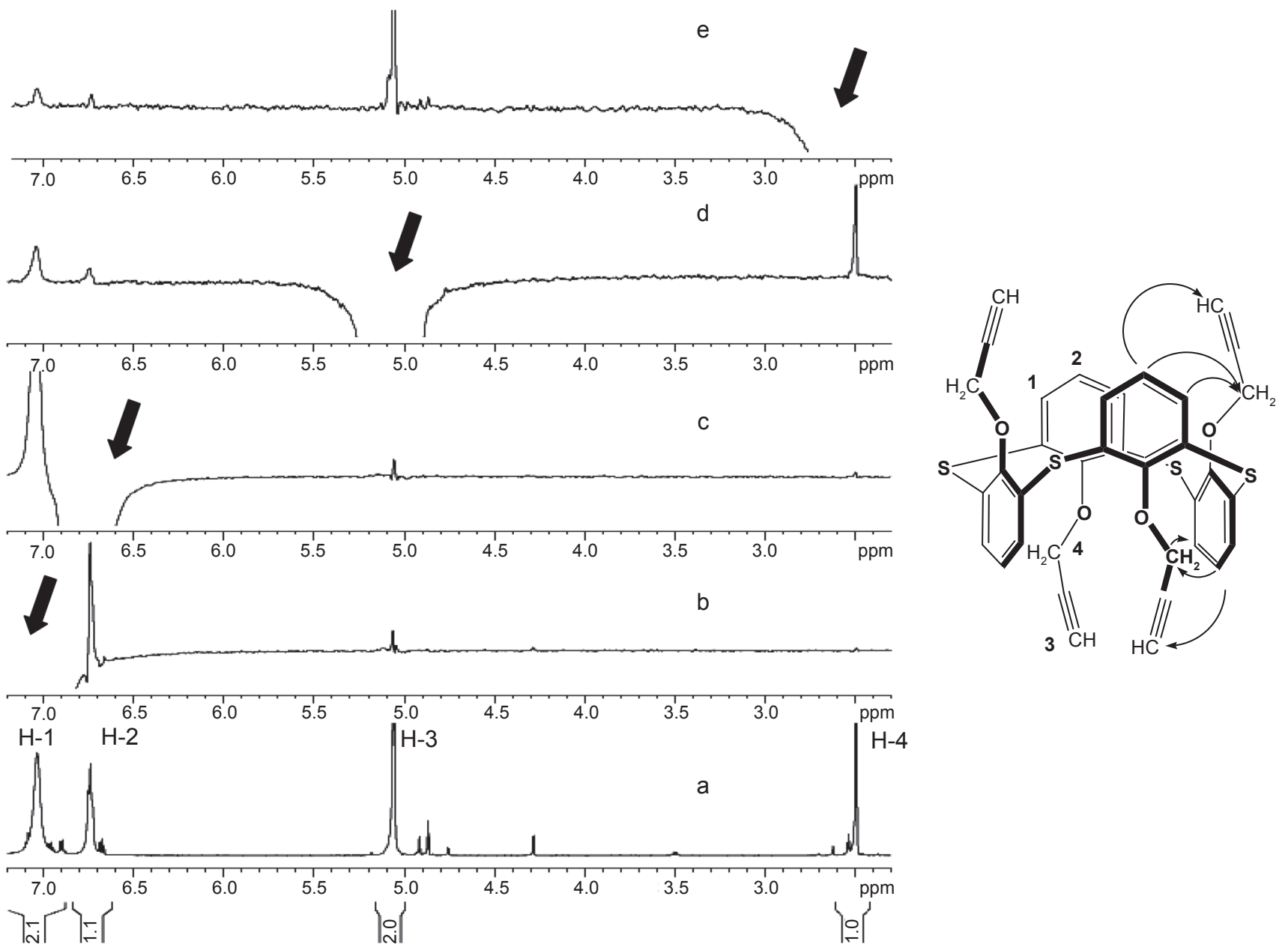

Figure 3. Identification of the 1,3-alternate stereoisomer 3b: ${ }^{1} \mathrm{H} \mathrm{NMR}\left(600 \mathrm{MHz}, \mathrm{CDCl}_{3}, \mathrm{~T}=303 \mathrm{~K}\right)$ spectrum (a), DPFGNOE spectrum with H-1 irradiated (b), DPFGNOE spectrum with H-2 irradiated (c), DPFGNOE spectrum with H-3 irradiated (d), DPFGNOE spectrum with H-4 irradiated (e). Excited protons are marked by array. 
Acknowledgements. We thank RFBR grant $\mathrm{N}^{\circ} 10-03-00728$ for financial support.

\section{References}

1. Kolb H.C., Finn M.G., Sharpless K.B. Angew. Chem. Int. Ed. 2001, 40, 2004-2021.

2. Morohashi N., Narumi F., Iki N., Hattori T., Miyano S. Chem. Rev. 2006, 106, 5291-5316.

3. Solovieva S.E., Popova E.V., Omran A.O., Gubaidullin A.T., Kharlamov S.V., Latypov Sh.K., Antipin I.S., Konovalov A.I. Russ. Chem. Bull., Int. Ed. 2011, 60, 486-498.

4. Dyker G., Mastalerz M., Müller I.M. Eur. J. Org. Chem. 2005, 3801-3812.

5. Klenke B., Friedrichsen W. J. Chem. Soc. Perkin Trans. 1 1998, 3377-3379.

6. Matthews S.E., Felix V., Michael G.B. Drew, Beer P.D. Org. Biomol. Chem. 2003, 1, 1232-1239.

7. Lhota'k P., Himl M., Stibor I., Sykora J., Cisarova I. Tetrahedron Lett. 2001, 42, 7107-7110.

8. Desroches C., Lopes C., Kessler V. Parola S. Dalton Trans. 2003, 2085-2092.

9. Xu W., Vittal J.J., Puddephatt R. J. Can. J. Chem. 1996, 74, 766-774.

10. Chen X., Dings R.P.M., Nesmelova I., Debbert S., Haseman J.R., Maxwell J., Hoye T.R., Mayo K.H. J. Med. Chem. 2006, 49, 7754-7765.

11. Chetcuti M.J., Devoille A.M.J., Ben Othman A., Souane R., Thuery P., Vicens J. Dalton Trans. 2009, 2999-3008.

12. Gordon A.J., Ford R.A. Chemists Companion: A Handbook of Practical Data, Techniques. New York, London, Sydney, Toronto: Wiley Interscience, 1972. 537 p.

13. Akdas H., Bringel L., Graf E., Hosseini M.W., Mislin G., Pansanel J., Cian A.D., Fisher J. Tetrahedron Lett. 1998, 39, 2311-2314.

14. Kumagai H., Hasegawa M., Miyanari S., Sugawa Y., Sato Y., Hori T., Ueda S., Kamiyama H., Miyano S. Tempahedron Lett. 1997, 38, 3971-3972.

15. Calixarenes: A Versatile Class of Macrocyclic Compounds. [Vicens J., Bohmer V., Eds]. Boston: Kluwer Academic Publishers, 1991. 264 p.

16. Lhotak P., Himl M., Pakhomova S., Stibor I. Tetrahedron Lett. 1998, 39, 8915-8918.
17. Lang J., Vlach J., Dvorakova H., Lhotak P., Himl M., Harbal R., Stibor I. J. Chem. Soc., Perkin Trans. 2 2001, 576-580.

18. Lhotak P., Himl M., Stibor I., Petrickova H. Tetrahedron Lett. 2002, 43, 9621-9624.

19. Konovalov A.I., Antipin I.S. Mendeleev Commun. 2008, 18, 229-237

20. Stoikov I.I., Omran O.A., Solovieva S.E., Latypov Sh.K., Enikeev K.M., Gubaidullin A.T., Antipin I.S., Konovalov A.I. Tetrahedron 2003, 59, 1469-1476.

21. Solovieva S.E., Gruener M., Omran A.O., Gubaidullin A.T., Litvinov I.A., Habicher W.D., Antipin I.S., Konovalov A.I. Russ. Chem. Bull. 2005, 54, 2104-2112.

22. Antipin I.S., Solovieva S.E., Stoikov I.I., Vershinina I.S., Pribylova G.A., Tananaev I.G., Myasoedov B.F. Russ. Chem. Bull. 2004, 53, 127-132.

23. Konovalov A.I., Antipin I.S., Mustafina A.R., Solov'eva S.E., Pod'yachev S.N. Russ. J. Coord. Chem. 2004, 30, 227-244.

24. Solov'eva S.E., Omran A.O., Gruener M., Habicher W.D., Antipin I.S., Konovalov A.I. J. Struct. Chem. 2005, 46 (Suppl.), S16-S21.

25. Kozlova M.N., Ferlay S., Solovieva S.E., Antipin I.S., Konovalov A.I., Kyritsakas N., Hosseini M.W. Dalton Trans. 2007, 5126-5131.

26. Solovieva S.E., Kleshnina S.R., Kozlova M.N., Galiullina L.F., Gubaidullin A.T., Latypov Sh.K., Antipin I.S., Konovalov A.I. Russ. Chem. Bull. 2008, 57, 1477-1485.

27. Tyuftin A.A., Solovieva S.E., Muravev A.A., Polyantsev F.M., Latypov Sh.K., Antipin I.S. Russ. Chem. Bull., Int. Ed. 2009, $58,145-151$.

28. Kozlova M.N., Ferlay S., Kyritsakas N., Hosseini M.W., Solovieva S.E., Antipin I.S., Konovalov A.I. Chem. Commun. 2009, 2514-2516.

29. Solov'eva S.E., Murav'ev A.A., Latypov Sh.K., Antipin I.S., Konovalov A.I. Dokl. Chem. 2011, 438 (Part 2), 170-174.

30. Solovieva S.E., Muravev A.A., Zakirzyanov R.T., Latypov Sh.K., Antipin I.S., Konovalov A.I. Macroheterocycles 2012, $5,17-22$.

31. Latypov Sh., Epifanova N., Popova E., Vasilevsky S., Solovieva S., Antipin I., Konovalov A. Appl. Magn. Reson. 2011, 41, 467-475.

32. Kasyan O., Rudzevich V., Bolte M., Bohmer V. J. Chem. Crystallogr. 2011, 41, 332-337.

33. Lhotak P., Himl M., Stibor I., Sykora J., Dvorakova H., Lang J., Petrickova H. Tetrahedron 2003, 59, 7581-7585. 